\title{
Live Experiences of Badjao* Street Children in Cabanatuan City, Philippines: A Phenomenological Approach
}

\author{
Laura A. Dator ${ }^{1}$, Anthony B. San Pedro², Josephine Reyes ${ }^{3}$ \\ ${ }^{1}$ Provincial Human Resource Management Office, Provincial Government of Nueva Ecija, Palayan City, Philippines \\ ${ }^{2}$ Provincial Cooperative and Entrepreneurship Development Office, Palayan City, Philippines \\ ${ }^{3}$ City Human Resource Management Office, Local Government Unit of Cabanatuan City, Cabanatuan City, Philippines \\ Email: anthonybasasanpedro@yahoo.com
}

How to cite this paper: Dator, L.A., Pedro, A.B.S. and Reyes, J. (2018) Live Experiences of Badjao Street Children in Cabanatuan City, Philippines: A Phenomenological Approach. Open Access Library Journal, 5: e4264.

https://doi.org/10.4236/oalib.1104264

Received: December 17, 2017

Accepted: January 22, 2018

Published: January 25, 2018

Copyright ( $\odot 2018$ by authors and Open Access Library Inc.

This work is licensed under the Creative Commons Attribution International License (CC BY 4.0).

http://creativecommons.org/licenses/by/4.0/

\begin{abstract}
This phenomenological research examines the situation of Badjao Street Children specifically about their daily routines in the street and the culture related reason for going back in the street despite the decent life which the government has planned in their newly built homes. The study utilizes the qualitative phenomenological research and used interview guide questions and observation checklist. The findings were analyzed using ngColaizzi's method. The results of findings show that the age of most Badjao street children ranges from 10 to 12 years old, male and are grade 3 students. Regarding their routines, they attend school, help their family by assisting in the household and by taking care of their siblings. They also go on streets to beg and ask for help, especially those who do not go to school. The routines of these children, especially begging may be attributed to the poverty which their families are experiencing when they transfer to Cabanatuan City. They are used to the works of the sea and are not used to jobs which they can do on the land. They resulted in begging since they do not know other ways of finding money to spend on their foods and other daily expenses. This research recommends intervention programs like livelihood training, values formations, and education.
\end{abstract}

\section{Subject Areas}

Sociology

\section{Keywords}

Phenomenology, Badjao, Collaizzi's, Street Children

*The term Badjao represents an indigenous community in Mindanao, one of the main islands of the Archipelago. 


\section{Introduction}

The Philippines is a country with the distinct culture. It has an estimated 14 - 17 million Indigenous People (IPS) belonging to 110 ethno-linguistic groups [1]. In Nueva Ecija alone where the study area is situated, there are 29,976 individuals composing 6338 indigenous families [2]. The indigenous communities are named based on their locale and niche. But today, most of their aborigines live outside the communities; they have been used to, one of which is the community of Badjaos.

The Sama-badjao tribes came from south-western Mindanao and are known differently among Filipinos as sea-dwellers [3]. They live in the sea, and their houses are built within the waters. They are used to earning a living from the water as most heads of the families are fishermen and pearl finders/hunters while Badjao mothers are mostly pearl and fruit vendors (Ibid)). These "sea gypsies" known as Badjao, were among those who are displaced and forced into destitution following the armed confrontation between government forces and rebels from the Moro National Liberation Front in September 2013 at Zamboanga City. "That violence killed nearly 200 people, displaced more than 100,000 residents, and destroyed thousands of homes [4].” The city's ethnic minorities, including the Badjao, were particularly vulnerable to displacement and forced relocation following the fighting. With such flight, these Badjao families have gone exploring in different places from Mindanao to various cities and provinces including Manila, Batangas and in Nueva Ecija [5]. The new environment of these people had also made changes in their lives and in their routines since they are used to what is brought by the sea waters and not by the land.

During the early rise of Bajao people in Nueva Ecija, their ordinary residence was the Central Transport Terminal of Cabanatuan City and the streets of the town proper. With a large number of families from the tribe, the Department of Social Welfare and Development (DSWD) have devised a program for housing and development which had the 391 Badjao families as the pilot beneficiaries in early 2017 [6]. The DSWD for Sama-Badjaos and its Core Shelter Assistance Program (CSAP). The program started the elevation and decency of the lives of Badjao people and their children.

Despite the move of the government to assist these families, many have not stopped working in the streets to beg, allowing children to stay on the roads with the risks of running for jeepneys. Children of the Badjao community are mostly with other children begging for coins, giving letters of solicitation in white envelopes and folders and singing in exchange of coins or any amount. Some children are carried by their mothers, including infants, while seeking for compassion. They became the common site in the Transport Terminal or near malls and bus stop. They became seeming street dwellers for those who do not know that houses are built and awarded for them and their families. Lives of these children became a risk as they became prone to street accidents and physical diseases which may be caught due to the changes in the weather and the envi- 
ronment.

This case study examines the situation of Badjao Street children specifically their daily routine in the street and the culture-related reasons for going back in the street despite the decent life which the government has planned in their newly built homes. The study will be used as the basis for the development of a holistic intervention program for street children in answering the empirical needs of their families and to determine solution on issues related to their educational needs and health.

\subsection{Significance of the Study}

This study will be significant to the Badjao street children, Badjao community, the Provincial Government of Nueva Ecija-Provincial Social welfare and Development Office (PGNE-PSWDO), the researcher and future researchers.

The Badjao street children will be benefited by the output of this study. It will provide programs and activities which may assist the Badjao street children in improving their lives. This study will also help the people around them understand them. In relation, it will also correct the misconceptions stereotyping the minds of the people in the province about the Badjao community. The society will also give them more positive regard as the Provincial government makes interventions.

Likewise, Provincial Government of Nueva Ecija-PSWDO will have an overview of the Badjao children in Cabanatuan City and in nearby towns. They may utilize the output of this study in assisting the Badjao community in the province. As part of the Provincial Government, the researcher may also become part of the team which will give intervention activities for the Badjao community. She may provide inputs learned from the interviews which she conducted with the Badjao children. This study also provided her in-depth knowledge about the conduct of an action research.

Lastly, future researchers who would like to conduct similar study may use this as their reference, guide, and literature review.

\subsection{Statement of the Objectives}

This study aims to examine the lives of Badjao street children in Cabanatuan

City. Specifically, it will have the following objectives:

1) To describe the profile of Badjao street children regarding:

a) age;

b) sex;

c) number of siblings;

d) educational attainment;

e) occupation of parents; and

f) household/residence.

2) To describe the Badjao children's way of life.

3) To determine the culture of Badjaos which are reflected in their lived expe- 
riences.

4) To develop an Intervention program for Badjao Street Children based on the findings of the study.

\section{Methodology}

This chapter presents the designs and frameworks used in the study. It will also include the respondents and tools used in the analysis of data.

\subsection{Conceptual Framework}

This study used the input-process-output as a conceptual design. In the conduct of the study, the inputs were:

1) the profile of the Badjao Street Children,

2) number of siblings, educational attainment,

3) occupation of parents and household/residence;

4) daily routine of Badjao street children including their daily meals,

5) street routines,

6) play time,

7) hygiene routines, and

8) schooling; and the adaption of these children to their culture. To gather and analyze data, interview and observations have been used. The data gathered were analyzed using the Collaizi Method. Findings of the study will become the basis for the development of an Intervention Program for Badjao Street children (Figure 1).

INPUT

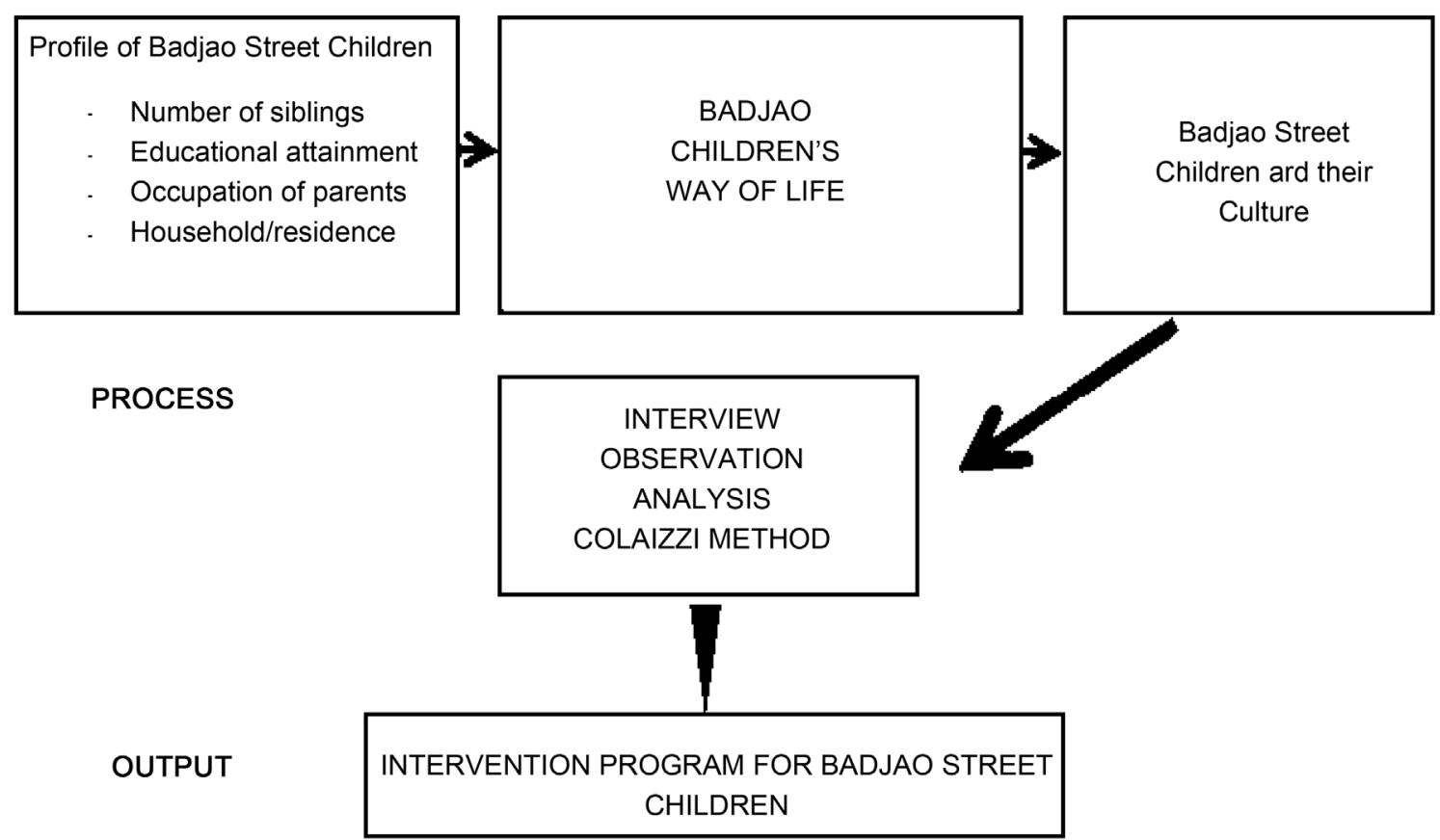

Figure 1. Research paradigm. 


\subsection{Research Design}

This study utilized the qualitative phenomenological study. Phenomenological research design focuses on the experiences of an individual or group. It attempts to understand people's perceptions, perspectives, and understandings of a particular situation. In this study, the phenomenological research design was used in examining the experiences of Badjao street children and their perception of the occurrence of their situations in the street and in daily living.

This study used interview guide questions and observation checklists.

\subsection{Respondents}

The respondents of the study will be five (5) Badjao Street Children in Cabanatuan City. The limited number of children interviewed is due to the following reasons: First, a permit has to be secured from the City Social Welfare and Development Office; Second, since the children are minors, consent from parents must be sought and not all parents allowed their children to be interviewed. Third, there was only few children who became willing to respond to the researcher. Most of them do not want to answer the questions. They seem to be afraid and shy. And lastly, there were only few children who qualified to the criterion set for the purposive sampling technique.

The location of these children will be from the Central Transport Terminal, from the Cabanatuan Public Market, Cabanatuan City Crossing, Maharlika Highway and Circumferential Road. These children will be selected using purposive sampling, a non-random sampling technique which is used to limit the sample based on a criterion set (Bernardez, 2011). In this study, the purposive criterion will be a) two years resident of Cabanatuan City; b) Badjao child whose age is 12 years and below; and c) frequently walking in the street to beg.

\subsection{Analysis}

In the analysis of findings, the Collaizi method was used. The method was used in determining the profile of the respondents, the daily routines and the culture of Badjao street children. This method made use of 7 steps in analyzing information and gathered evidence for case study and other qualitative researches. The steps were as follows: 1) The respondents' descriptions of their experiences were recorded and noted. The transcript was reviewed several times for deeper understanding of the content; 2) Significant statements were formulated from the transcript. These statements were written on different sheets; 3) Those significant statements were interpreted. Each meaning was coded in one category based on description; 4) The formulated meanings are organized. The formulated meanings were grouped into categories wherein each category represented a structure of the cluster of themes; 5) The organized meanings were integrated into thorough description; 6) The essential structure of the phenomenon was formulated. In this step, a reduction of findings was done. Redundancies, misused descriptions were eliminated; and 7) Validation of study findings was the 
last [7].

\section{Results and Discussions}

This chapter presents the findings and interpretation of data based on qualitative analysis. Results are tabulated, and implications are drawn.

\subsection{Profile of Badjao Street Children}

The Table 1 shows the profile of the respondents. Findings show that the age of most Badjao street children range from 10 to 12 years old, male and are grade 3 and average siblings of 3 to 6 . The occupation of the parents shows that fathers are mostly vendors of pearl while mothers are not working. This indicates that Badjao children have sacrificed their schooling since their age is not the average age of a grade 3 student. The typical occupation of adults is pearl peddling since they live in waters and most makes themselves busy fishing and finding or hunting for pearls [8]. Being called "sea dwellers", they are used to the job. Since their houses are built on the sea, they are expert in waters. Thus, in their community, the water has been their source of income. They earn money with jobs related to the sea including pearls in the water and selling these pearls to the town and cities nearby. The sea is also filled with fishes, thus, fishing was also part of their income sources. Since they used to job related to water, they had difficulty adjusting their lifestyle and works when they transferred in Nueva Ecija.

\subsection{Daily Routines of Badjao Street Children}

The daily routines of Badjao street children are described regarding their daily meals, street routines, play time, and schooling.

Repertory Grid 1 shows the regular routines of Badjao street children. Significant statements show that they attend school, helps their family by assisting in the household and by taking care of their siblings. They also go on streets to beg and ask for help, especially those who do not go to school. The routines of these children, especially begging may be attributed to the poverty which their families are experiencing when they transfer to Cabanatuan City. They are used to the works of the sea and are not used to jobs which they can do in the land. Schooling is a priority for some but not for all, as there are those who are on the street

Table 1. Profile of Badjao street children.

\begin{tabular}{ccccccc}
\hline Respondent & Age & Gender & $\begin{array}{c}\text { Educational } \\
\text { Attainment }\end{array}$ & $\begin{array}{c}\text { No. of } \\
\text { Siblings }\end{array}$ & $\begin{array}{c}\text { Occupation } \\
\text { of Mother }\end{array}$ & $\begin{array}{c}\text { Occupation } \\
\text { of Father }\end{array}$ \\
\hline A & 10 & Male & Grade 3 & 5 & None & Pearl vendor \\
B & 12 & Male & Grade 3 & 3 & Pearl vendor & Pearl vendor \\
C & 12 & Female & Grade 3 & 3 & None & Pearl vendor \\
D & 10 & Male & Grade 3 & 6 & None & Pearl vendor \\
E & 12 & Male & Grade 3 & 5 & None & None \\
\hline
\end{tabular}


Repertory Grid 1. Daily routines.

\begin{tabular}{|c|c|c|}
\hline Themes & Subthemes & Significant Statements \\
\hline Attends School & None & $\begin{array}{l}\text { "Gumigisingakongmaaga, tapos pang } \\
\text { luneshanggangbiyernes, puntaakosaeskuwelahan." } \\
\text { (Translation) I wake up early. from monday to } \\
\text { Friday, I go to school } \\
\text { "Gumigising din } \\
\text { akomaagaparapasoksaeskuwelahan" } \\
\text { "Nag-aaral" }\end{array}$ \\
\hline $\begin{array}{l}\text { Helps the } \\
\text { family }\end{array}$ & $\begin{array}{l}\text { Assists in the } \\
\text { household chores }\end{array}$ & $\begin{array}{l}\text { "Bagopumasok nag-iigibparagamitinngnanay" } \\
\text { "nagsasaing din ako" translation before going to } \\
\text { school I fetch water and help my } \\
\text { mother to cook rice }\end{array}$ \\
\hline & $\begin{array}{l}\text { Takes care of other } \\
\text { siblings }\end{array}$ & $\begin{array}{l}\text { "Nag-aalaga din akongkapatidko" } \\
\text { Translation: I also take care of my siblings }\end{array}$ \\
\hline Beg on Street & None & $\begin{array}{l}\text { "Pagwalangaralnamamalimosakokasamamgakapatid } \\
\text { at pinsanko" } \\
\text { "Sumasa din akosanamamalimos" } \\
\text { "Sakaysa jeep at hingingtulong" } \\
\text { "Magkakasama kami niSalmosapaghingingtulong." } \\
\text { "Gigisingngmaaga, taposmagkikita kami nila } \\
\text { Ramon at sabaynapuntangbayanparamamalimos" } \\
\text { "Namamalimoslang" Translation: When there is no } \\
\text { class we go out to beg }\end{array}$ \\
\hline
\end{tabular}

for the whole week to seek for help in their finances.

Repertory Grid 2 describes the daily meals of Badjao street children. Findings show that their meals are not regularly sustained. Their meals are dependent most of the time to the feeding in school which is not regular and are only given during a certain period. Thus, when there is no feeding, children will not have meals. They also eat depending on the amount of money begged. If the amount begged is not sufficient, they will only buy rice or just fish or canned goods which are not enough for the rest of the family. In indicates that Badjao children lack sufficient nutritious meal and may have tendencies for malnutrition.

Repertory Grid 3 discusses the daily street routines and play time of Badjao street children. Findings show that these children are on the street to beg. They run after jeepneys to sing and give solicitation letters. They play instruments or simply ask for money. Their play areas are the streets too. When there are still no jeepneys, they play and run after each other on the street. These findings imply that these children spend most of their time on the street. Their time is occupied by wanting to earn money for their family so that sufficient meal will be on their tables. Thus, an intervention program for their livelihood should be developed.

Repertory Grid 4 shows the description of their schooling. Findings show that not all Badjao street children are in regular schooling. Some prefer to stay on the street and beg than be in school to study. It is evident in their responses that because of the needs of their family, they stay begging on the street. There 
Repertory Grid 2. Daily meals.

\begin{tabular}{|c|c|c|}
\hline Themes & Subthemes & Significant Statements \\
\hline $\begin{array}{l}\text { Not Regularly } \\
\text { sustained }\end{array}$ & $\begin{array}{c}\text { Depending on } \\
\text { the begged } \\
\text { amount }\end{array}$ & $\begin{array}{l}\text { "May pidingnamansa school." } \\
\text { "Sa feeding sa school." } \\
\text { "Pasokako, Mayroon feeding sapaaralannamin," } \\
\text { "bigyan kami ng feeding" } \\
\text { Translation: I attend feeding sessions in school } \\
\text { "Pambilingbigas" } \\
\text { "Bilingbigas" } \\
\text { "Pambilingpagkain" } \\
\text { "Isdalang" } \\
\text { "Minsansardinaslang" } \\
\text { Translation: the amount we begged is used to buy food }\end{array}$ \\
\hline
\end{tabular}

Repertory Grid 3. Daily street routines and play time.

\begin{tabular}{|c|c|c|}
\hline Themes & Subthemes & Significant Statements \\
\hline \multirow{3}{*}{ Begging } & $\begin{array}{l}\text { Sings in } \\
\text { Jeepney }\end{array}$ & $\begin{array}{l}\text { "Kumakanta at tumutogtogng instrument." } \\
\text { "Kukanta din ako. baba kami sa may mcdo. } \\
\text { Tapossakayulitngdyipjeep." Translation, } \\
\text { we sing during begging }\end{array}$ \\
\hline & $\begin{array}{l}\text { Gives } \\
\text { solicitation } \\
\text { letters }\end{array}$ & $\begin{array}{l}\text { "Nagbibigayngsobre" } \\
\text { Habangsinasabi "kami po ay mgabadjao, } \\
\text { nawalapoangamingtirahansagiyera, hindipo } \\
\text { kami magnanakaw, salamatsanyongibibigay" } \\
\text { "Hahabolsa jeep, bigayko un envelope taposmamalimos." } \\
\text { Translation: we also give solicitation letters }\end{array}$ \\
\hline & $\begin{array}{l}\text { Ask for } \\
\text { money }\end{array}$ & $\begin{array}{l}\text { "Namamalimos at naglalaro" } \\
\text { "Sakaysa jeep at hingingtulong" } \\
\text { Translation: we beg and play at the same time }\end{array}$ \\
\hline Playing & & $\begin{array}{l}\text { "Malimoslang at naglalaro" } \\
\text { "Naglalaroakopagwala pa dyip" Translation: we beg and } \\
\text { play at the same time }\end{array}$ \\
\hline
\end{tabular}

Repertory Grid 4. Schooling.

\begin{tabular}{|c|c|c|}
\hline Themes & Subthemes & Significant Statements \\
\hline \multirow{4}{*}{$\begin{array}{l}\text { Attends School } \\
\text { Regularly }\end{array}$} & & "Gumigisingakongmaaga, tapos pang \\
\hline & & luneshanggangbiyernes, puntaakosaeskuwelahan." \\
\hline & & "Gumigising din akomaagaparapasoksaeskuwelahan" \\
\hline & & "Nag-aaral" Translation: We attend classes regularly \\
\hline \multirow{7}{*}{$\begin{array}{l}\text { Do not attend } \\
\text { school }\end{array}$} & \multirow{4}{*}{ Need Money } & "Para hingingkontingtulong \\
\hline & & Pambilingbigas" \\
\hline & & "PambilingPagkain" \\
\hline & & "Pambilingmakakin" Translation: we beg to buy foods \\
\hline & \multirow{3}{*}{ Prefers to Beg } & "Namamalimoslangaraw-araw" \\
\hline & & "gigisingngmaaga. Mamalimos" \\
\hline & & "Malimoslangakoatnaglalaro." Translation: We beg \\
\hline
\end{tabular}

are also some who do not have an interest in schooling are prefers to beg. This strongly supports the earlier findings that they need to be supported through a 
livelihood program so that regular earnings will be possible. Attention is also needed by those who prefer to beg than study. Intervention activities like counseling and outreach activities related to academic and values formation may be given to increase the declining interest of these children in studying. If these will not be paid attention, the number of Badjao people in Cabanatuan will just increase, but their economic status will not change. They will continuously beg on the street and ask for money instead of earning it.

\subsection{Analysis about the Culture of Badjao}

The Table 2 shows the culture of Badjao based on the lives of street children. Findings show that their primary source of income is in the sea and they are used to works which are coming from the sea like fishing and hunting for pearls. When they transferred to the dry land from where their skills for fishing and hunting pearls are not fitted, they resulted in begging. They need to do this since they do not know other ways of finding money to spend on their foods and other daily expenses.

It can also be seen that children at a young age are used to responsibilities at home and in helping their family to earn.

Table 2. Culture of Badjao based on the lives of street children.

\begin{tabular}{|c|c|c|}
\hline Classification & Way of Life & Significant Statement \\
\hline $\begin{array}{l}\text { Source of } \\
\text { Income }\end{array}$ & $\begin{array}{l}\text { Fishing, Pearl hunting } \\
\text { and Pearl peddling } \\
\text { (in their former } \\
\text { home) }\end{array}$ & $\begin{array}{l}\text { "Nagtitindasila at naglalakongperlas" } \\
\text { "Sumisisidtaposnaghahanapngperlas" } \\
\text { "mangingisdasitatay, } \\
\text { tapossinanaynamanangnagtitinda" } \\
\text { Translation: We also sell and hunt for a living }\end{array}$ \\
\hline \multirow{3}{*}{ Values } & $\begin{array}{l}\text { Begging on Streets } \\
\text { (in Cabanatuan) }\end{array}$ & $\begin{array}{l}\text { "namamalimospo kami kapagwalangpasok" } \\
\text { "namamalimospo" Translation: } \\
\text { we beg when there is no class }\end{array}$ \\
\hline & Family Orientedness & $\begin{array}{l}\text { "namamalimospoakoparamakatulongsapamilya" } \\
\text { "tinutulungan kop o sinanaysagawaingbahay." } \\
\text { Translation: We beg to help my mother earn a living }\end{array}$ \\
\hline & Family Responsibility & $\begin{array}{l}\text { "akopoang nag-iigibsabahay" } \\
\text { "nag-aalagapoakongkapatid.” Transaltion: } \\
\text { I perfrom household chores }\end{array}$ \\
\hline Routines & Begging & $\begin{array}{l}\text { "namamalimoslangpo kami } \\
\text { kapagwalangpasok" } \\
\text { "dun nap o kami } \\
\text { sakalyenalalarokapagwalangdyipnapapalimusan" }\end{array}$ \\
\hline \multirow[t]{2}{*}{ Food } & Fish & $\begin{array}{l}\text { "Isdapoangpagkainnamin" } \\
\text { "isdalang Po" } \\
\text { "sardinas" Translation: we ordinarily eat fish }\end{array}$ \\
\hline & Others & $\begin{array}{l}\text { "dependeposa feeding" translation: depending on } \\
\text { the feeding program }\end{array}$ \\
\hline
\end{tabular}




\section{Intervention Program}

Below is an intervention program which is developed to answer the needs of Badjao Street children and their family. This intervention is based on the findings of the study and is focused on the main reason for begging which is poverty and lack of other sources of income. The person who will be in-charge of the interventions will be the Provincial Social Welfare and Development with the help of the City Social Welfare and Development of Cabanatuan City. This may be conducted from January 2018 and may continuously be implemented in the succeeding years (Table 3 ).

\section{Conclusions}

Based on the findings of the study, the researcher concludes that Badjao people

Table 3. Intervention program which developed to answer the needs of Badjao Street Children \& their family.

\begin{tabular}{|c|c|c|c|c|}
\hline Concerns & Objectives & $\begin{array}{l}\text { Activities/ } \\
\text { programs }\end{array}$ & Resources & $\begin{array}{l}\text { Success } \\
\text { Indicator }\end{array}$ \\
\hline \multirow[t]{2}{*}{$\begin{array}{l}\text { Source of } \\
\text { Income }\end{array}$} & $\begin{array}{l}\text { Train Badjao adults } \\
\text { about different } \\
\text { skill-based jobs. }\end{array}$ & $\begin{array}{c}\text { Livelihood } \\
\text { training on } \\
\text { weaving, } \\
\text { mushroom } \\
\text { growing, animal } \\
\text { husbandry, pastry } \\
\text { making. } \\
\text { Initial funding of } \\
\text { the government } \\
\text { agencies involved. }\end{array}$ & $\begin{array}{c}\text { Private } \\
\text { agencies knew } \\
\text { in the field }\end{array}$ & $\begin{array}{l}50 \% \text { of Badjao } \\
\text { adults have } \\
\text { started the } \\
\text { business with } \\
\text { the initial } \\
\text { capital from } \\
\text { the supporting } \\
\text { agencies }\end{array}$ \\
\hline & $\begin{array}{l}\text { Math the skills of } \\
\text { badjao adults to } \\
\text { available job } \\
\text { opportunities }\end{array}$ & $\begin{array}{l}\text { Job hunting and } \\
\text { job fair with } \\
\text { training and } \\
\text { assistance }\end{array}$ & $\begin{array}{c}\text { Private } \\
\text { agencies, } \\
\text { communities, } \\
\text { and } \\
\text { individuals }\end{array}$ & $\begin{array}{l}30 \% \text { of badjao } \\
\text { adults found a } \\
\text { job fitted in } \\
\text { their skills }\end{array}$ \\
\hline $\begin{array}{l}\text { Out-of-School } \\
\text { badjao } \\
\text { children }\end{array}$ & $\begin{array}{l}\text { Enroll Badjao } \\
\text { children in school. } \\
\text { Find private } \\
\text { individuals who will } \\
\text { become sponsors of } \\
\text { the children's } \\
\text { schooling }\end{array}$ & $\begin{array}{l}\text { Mass enrollment } \\
\text { of Badjao } \\
\text { children. } \\
\text { "Send a child to } \\
\text { school Project" } \\
\text { for badjao } \\
\text { children }\end{array}$ & $\begin{array}{c}\text { Deped, private } \\
\text { individuals, } \\
\text { government } \\
\text { agencies } \\
\text { involved }\end{array}$ & $\begin{array}{c}90 \% \text { of badjao } \\
\text { children are } \\
\text { enrolled. } \\
50 \% \text { of Badjao } \\
\text { children are } \\
\text { beneficiaries } \\
\text { of "Send a } \\
\text { child to School } \\
\text { project." }\end{array}$ \\
\hline $\begin{array}{c}\text { Values } \\
\text { Formation }\end{array}$ & $\begin{array}{l}\text { Provide training to } \\
\text { build character and } \\
\text { moral reasoning of } \\
\text { Badjao children }\end{array}$ & $\begin{array}{c}\text { Weekly values } \\
\text { Formation } \\
\text { program } \\
\text { Group Dynamic } \\
\text { Activities } \\
\text { Bible Story Telling }\end{array}$ & $\begin{array}{c}\text { DepEd, } \\
\text { Psychologists, } \\
\text { Religious } \\
\text { groups, } \\
\text { private } \\
\text { individuals } \\
\text { and } \\
\text { government } \\
\text { agencies } \\
\text { involved }\end{array}$ & $\begin{array}{l}80 \% \text { of badjao } \\
\text { children will } \\
\text { attend the } \\
\text { Values } \\
\text { Formation } \\
\text { Program }\end{array}$ \\
\hline
\end{tabular}


are mainly concern of their daily earnings in order to feed their family. Since they are away from their original community which is the sea, they are not used to working on the land. This means that they have limited idea as to what works would suit them in their new community. This had been the reason why they spend their days begging in the streets. This culture was adapted by the Badjao Street children. They value earning money more than schooling because this is what they see from their parents. They need to make to every day fruitful by earning money. At an early age, they were oriented to the household needs, from the domestic chores to the means of finding meals for the family. This reflects the common Filipino values in their culture which is the "family first" principle.

Additionally, it can be concluded that if the Government would be able to provide programs which will orient the Badjao men and women on works which will make them progressive in the land, they will leave the streets. Some may think that Badjaos beg because they do not want to work, but the real thing is Badjao regard begging as work, the easiest and the simplest work they know. This is so because they are not aware of other possible means to earn money for the daily meals. With these thoughts, interventions from the government in terms of livelihood trainings will be a great help in changing their lives and making their children schooled.

However, this study must be supported by future studies since it only has five participants and the locales are limited to Cabanatuan City selected area. There were other cities in Nueva Ecija were Badjao people lives. A replication of this study will greatly support and enhance the findings and intervention program which may be served and utilized by the government. An interview to the parents as form of validating the responses of the children may also be done. It will make the result stronger and more reliable.

Still with the conclusions and limitations, the researcher is highly recommending that the Intervention Program which is the output of this study be utilized.

\section{References}

[1] Bernardez, E.T. (2011) Methods of Research. Lorimar Publishing House, Cubao Quezon City.

[2] Gabriel, A.G. and Mangahas, T.L.S. (2017) Indigenous People's Contribution to the Mitigation of Climate Variation, Their Perception, and Organizing Strategy for Sustainable Community Based Forest Resources Management in Caraballo Mountain, Philippines. Open Journal of Ecology, 7, 85-100. https://doi.org/10.4236/oje.2017.72007

[3] Author (2017) Cabanatuan Badjao Live in Pilot Housing. Nueva Ecija Journal, 3, 4.

[4] Campo, L.G. (2103) The Badjaos: Their Real Story. Philippines Star. http://www.philstar.com/

[5] Conde, C.H. (2013) The Philippine Image of Badjao Displacement. Sunstar Cagayan D Oro. http://www.sunstar.com.ph

[6] Sosha, G.A. (2012) Employment of Colaizzi's Strategy in Descriptive Phenomenology. A Reflection of a Researcher. European Scientific Journal, 8, ISSN: 1857-7881. 
[7] United Nations Development Programs (2010) Fast Facts. http://www.undp.org/

[8] Velaso, V. (2014) Badjao Boy Lives on Street Scraps to Goto School. Business Mirror. www.businessmirror.com.ph 